J O U R N A OF French and Francophone Philosophy
RE VUE DE LA

philosophie française et de langue française

\title{
To Dwell for the Postcolonial
}

\section{Grant Farred}

Journal of French and Francophone Philosophy - Revue de la philosophie française et de langue française, Vol XX, No 1 (2012) pp 75-86.

\author{
Vol XX, No 1 (2012) \\ ISSN 1936-6280 (print) \\ ISSN 2155-1162 (online) \\ DOI $10.5195 /$ jffp. 2012.538 \\ www.jffp.org
}

\section{(oc) BY-NG-ND}

This work is licensed under a Creative Commons Attribution-Noncommercial-No Derivative Works 3.0 United States License.

\section{ULIS D-Sunt}

This journal is operated by the University Library System of the University of Pittsburgh as part of its D-Scribe Digital Publishing Program, and is co-sponsored by the University of Pittsburgh Press 


\title{
To Dwell for the Postcolonial
}

\author{
Grant Farred \\ Cornell University
}

Introduction

Everyone can think what he likes, provided however that he thinks.

- Jean-Paul Sartre, Preface, The Wretched of the Earth

Perhaps everything needs to be started over again.

- Frantz Fanon, The Wretched of the Earth

It is doubtful that either Jean-Paul Sartre or Frantz Fanon would have understood himself as operating under the Heideggerian injunction, but that is precisely what they are doing. In Alain Badiou's estimation, offered in The Clamor of Being, Martin Heidegger is the philosopher of the twentieth century. Heidegger holds this status for Badiou because of his attention to temporality and thinking. Sartre, it would seem, does not only understand the importance of thinking but it constitutes for him a prerequisite for participation in the political: "Everyone can think what he likes, provided however that he thinks." For Heidegger, however, thinking, if it takes place, is almost indistinguishable from truth, so Sartre's demand - "provided however that he thinks" - would strike Heidegger as a serious inability. For Heidegger to think is to grasp the truth, or, to come to truth through thinking, or, to know truth as thinking. In Heideggerian terms, Sartre's tolerance, articulated as the conditional (the provisional), "provided," reveals itself as a grievous mistake: the forming of an opinion is not thinking.

According to Rüdiger Safranksi, one of Heidegger's biographers, and to Heidegger himself, nothing matters quite as much as beginning, a truism if there ever was one, at the beginning. "'Philosophizing,'” Heidegger was known to assert, "'ultimately means nothing other than being a beginner'." Thinking from the beginning, is an invitation - the most direct form of 
address, a challenge, a call to thinking - that Fanon issues to the postcolonial in The Wretched of the Earth. Fanon's invitation, however, is seldom heard, and even less frequently taken up. But there can doubt about its clarity: "Perhaps everything needs to be started over again." Not simply "started over again," but "everything" - which means that nothing can be excluded, beginning with the postcolonial itself because that is the site of Fanon's greatest resonance - must be made a matter for consideration. As Heidegger says about the "Old German words thing and dinc," so the postcolonial must, now under the sign of the beginning, "become the name for an affair or a matter of pertinence" ${ }^{2}$ because the Fanonian articulation of the word "postcolonial" is now being returned to itself, remanded to a "first" thinking that is not a first thinking but a call for a thinking of how The Wretched of the Earth starts (a) thinking of the postcolonial.

All that Fanon fought for The Wretched of the Earth, struggled for in Black Skins, White Masks, the radical political imagining that saturates his work, the philosophical imperative that shapes it insistently, those struggles for which he gave his life, "everything," must be assigned a propositional "pertinence." Not least of all, in this act of starting everything again, is the importance of recognizing the interrogative Frantz Fanon issues himself, and those who engage him: thinking Frantz Fanon must begin again, it is a project that must be started over. That is because of the all-inclusive "perhaps." In the Fanonian articulation there is inscribed in "perhaps" a political charge that exceeds the propositional, an excess that returns, upon different terms, to the beginning. To the beginning, a beginning, that both is and is not overdetermined by the moment - either the historic significance of the fiftieth anniversary of the publication of The Wretched of the Earth or the condition of the extant postcolonial. Thinking, the postcolonial of (started, inaugurated by) The Wretched of the Earth in this instance, is only possible if it accepts as its primary condition, its proper first name, (the) "perhaps."

The "perhaps" requires the reluctant eschewing of the propositional, that which offers itself, however tentatively, as an answer, in favor of the suppositional, that which begins with only the proviso - the provisional. In the suppositional, it is possible that things might be so but, also, that they might not. It is in this way that the suppositional - "perhaps" - allows for the opening into thinking by assigning, to everyone, the designation beginner. If everyone is a beginner, then everyone might begin to think the postcolonial from the position of a shared suppositional; a suppositional, it should be added, that cannot ever be fully disarticulated from the propositional. Or, to invoke Sartre's phrasing in philosophical terms recalibrated by Heidegger and Fanon's work, "Everyone can think what he likes" as long as she or he begins with "perhaps." The signal possibility that the "perhaps" of The Wretched of the Earth offers is, poorly phrased (in terms of how Heidegger thinks the concept in Being and Time), temporality. 
However, reductive as such a gesture might be, the Fanonian "perhaps" makes possible a thinking of the postcolonial that begins not with its end (a discourse all too familiar to us), or, from its having ended (in abjection, in failure), but as The Wretched of the Earth's thinking a "starting over again."

Fanon's phrasing is succinct, but clear. This is not a new beginning, itself always only a putative possibility, but a starting over again. Starting over again demands a working with, a working over, if you will, extant conditions. Starting over attends to what is but refuses the very (necessary) delimitations of what is. It is a difficult project, to start over again, iterated already in the acknowledgement - starting over "again" - that such an imagining has a previous life (or, lives) but there is, as Fanon and Heidegger both remind us, no substitute for thinking again: making the "perhaps" of The Wretched of the Earth a supposition of pertinence. Heidegger, more than Fanon, is concerned with what is lost in the overuse of terms so that staring over again for him recognizes that "true meaning falls easily into oblivion in favor of foreground meanings." ${ }^{3}$ However, Heidegger also understands both the retrievability - the recovery, the making audible again - of the "true meaning" and the kind of interrogation that is needed to achieve it: "its primal call does not thereby become incapable of speech; it merely falls silent." ${ }^{4}$ In The Wretched of the Earth instance it is, of course, not the postcolonial that has "fallen silent;" it is, rather, that the "perhaps" was never (fully) heard. Its suppositionality (and its propositionality) was not only superseded by the romance of the postcolonial - the promise of "starting over" after colonialism, which is in truth a starting, is the only "starting over" imaginable, despite Fanon's warnings and cautions in The Wretched of the Earth. More pertinently, the "perhaps" was rendered inaudible, without any possibility of being heard, let alone taken up as a project for thought, a project already audible, ominously so, in The Wretched of the Earth. After all, Fanon warns, "We must not expect the nation to produce new men," ${ }^{5}$ a declarative inaudible except as a command to thinking - at the very least, a call for the interrogative, an explication for why there will be no "new men." If the "new nation" cannot be "expected" to "produce new men," then this shortcoming constitutes a serious flaw in itself - considering Fanon's attention to constructing a new political consciousness, a new thinking of the anti-colonial Self, in The Wretched of the Earth. At the very least, then, because of this, the "new nation" must "produce" a thinking about itself, a thinking about how it thinks; or, fails to think about what it is not thinking about.

If the "nation" cannot produce "new men," that is, a thinking disjoined from its colonial(ist) antecedent, then it is not, in Heidegger's terms, a nation fit for dwelling. This is a project, dwelling, that girds The Wretched of the Earth. The postcolonial nation of The Wretched of the Earth is not, in Heideggerian terms, a building - broadly understood as the making, the constructing, the making possible of, that "space" - in which the 
postcolonial can dwell; in which the postcolonial can be. As Heidegger understands, it is no small thing to dwell. For Heidegger to dwell means to be

set at peace, means to remain at peace within the free, the preserve, the free sphere that safeguards each thing in its nature. The fundamental character of dwelling is this sparing and preserving. It pervades dwelling in its whole range. That range soon reveals itself to us as soon as we reflect that human beings consist in dwelling and, indeed, dwelling in the sense of the stay of mortals on the earth. ${ }^{6}$

In the most fundamental Heideggerian terms possible, dwelling is nothing less than Being. That is, dwelling is everything because "human being consist in dwelling." These are the terms on which The Wretched of the Earth must be approached: as Fanon's struggle to build the postcolonial as house for dwelling. That is the house that The Wretched of the Earth seeks to build, that is the house that thinking must now undertake, again (perhaps even over and over again), to build. Because building does not always, or necessarily, produce a dwelling - that in which the "fundamental character" of Being, Dasein, can be revealed, in which postcolonial Being can be "spared and preserved," it is dwelling that must be the first order of postcolonial business. The call for a dwelling for postcolonialism is, in this Heideggerian way, the work that thinking must undertake; this is what the Fanonian "perhaps" makes audible; it is the making of a dwelling that must be sought for, built, in the act of "starting over again." If the postcolonial dwelling is yet to be built, if the house in which postcoloniality can be has not yet been constructed, then it becomes imperative to understand that thinking postcolonialism as that which is yet to be thought is the task that The Wretched of the Earth sets.

\section{To Dwell for the Postcolonial}

Enough will have been gained if dwelling and building have become worthy of questioning and thus have remained worthy of thought.

- Martin Heidegger, "Building Dwelling Thinking"

The Third World must not be content to define itself in relation to values which preceded it.

- Frantz Fanon, The Wretched of the Earth 
The political imperative for Fanon, to make the nation after colonialism, translates as an address to the Heideggerian question: how to make a building in which the postcolonial can dwell? It is a question audible in so fundamental a biopolitical register as to be almost Agambenian: how to spare and preserve life? In Giorgio Agamben's terms, of course, the terms would be read as "zoe" and "bios" - bare life and political life. These are, needless to say, critical issues, issues that have preoccupied postcolonial scholars for at least three generations now.

From the very beginning, however, Fanon's attention is both on the fundamental - which we might understand as the ongoing political struggle against, inter alia, inequity - and the inaugural. That is, with the beginning, that which understands its own precariousness, that which refuses the known - "The Third World must not be content to . . " However, salient as his refusal of the dialectic is in this instance, much of Fanon's thinking is prone to precisely this mode of thinking. Nowhere is Fanon's dialectical materialism more evident than in "On Violence." "The basic confrontation," he writes, "which seemed to be colonialism versus anticolonialism, indeed capitalism versus socialism, is already losing its importance. What matters today, the issue which blocks the horizon, is the need for a redistribution of wealth." ${ }^{7}$ Here Fanon's thinking moves, rapidly, from the dialectic to what might seem like a synthetic call - for the "redistribution of wealth" - but it ends, in truth, with nothing but a declarative that spawns a further dialectic: "Humanity will have to address the question [of redistribution], no matter how devastating the consequences might be." 8

It is because of Fanon's proclivity for the dialectical and the declarative, however, that his brief turn from the former reveals the significance of the "perhaps." In starting over, even if only for a moment, there can be no vitalization of the dialectic, itself issued, true to Fanonian form, as the declarative, albeit a far more tentative one than is at first apparent: "The Third World must not be content to define itself in relation to values which preceded it." A double break is articulated here: (1) from the culture of the colonizer, itself, of course, an impossible sundering; and, (2) contra Fanon's celebration of the colonized's culture, the implicit recognition that there can be no (easy) hearkening to pre-coloniality. It is out of this aporia, the declarative that is grounded in nothing so much as uncertainty, that Fanon confronts at once the limits and the advantages of the dialectic. The dialectic derives its force from the oppositional, it provides something that can be argued against as well as struggled for. This, of course, is also its limit because every position must be measured, measure itself, against its antithesis. In its own way, the dialectic works, for all its gainsaying, primarily through the force of mediation.

If the dialectic is suspended, the question inherent in Fanon's articulation persists: to which "values" will the postcolonial turn having recognized that it now operates under the terms of the double break? That 
neither the immediate nor the distant past will suffice as models of thought? It is here that the "perhaps" comes into its own and it does so neither as the propositional nor the suppositional but as a sovereign "starting over." The question that The Wretched of the Earth poses is one that Fanon cannot answer. He is vague, generic, unhelpfully categorical in addressing his own interrogative: "underdeveloped countries must endeavor to focus on their very own values as well as methods and style specific to them." ${ }^{9}$ The only force that sustains Fanon's critique of "values" is his repeated turn to thinking from the beginning; or, thinking as that act that marks the beginning of the postcolonial. Fanon's skepticism about the "new," his insistence on the insufficiency of the transition of political power from the colonizer to the colonized, persists: "The country finds itself under new management, but in actual fact everything has to be started over from scratch, everything has to be rethought." ${ }^{10}$ The refrain of "starting over" is constant, buttressed in this instance by the determination that "everything has to be rethought."

The Wretched of the Earth, for all Fanon's commitment to the redistribution of wealth and resources, reveals itself as a work struggling, sometimes despite itself, even sometimes, it seems, unknown to itself, with the Manicheanism of the Cold War. That is, The Wretched of the Earth cannot, in its most philosophical moments (when thinking, not the political declarative, prevails), countenance either socialism or capitalism. Of course, Fanon has far greater regard for socialism, but The Wretched of the Earth is a struggle for what Heidegger names, elusively, the "unconcealedness of what is already there."11 We might even name Fanon's grasping for "values," although it seems that it is something else that he is reaching for, a desire for a postcolonial élan vital - a more vital mode of postcolonial life, one in which a Heideggerian dwelling might be discerned. That is, where the "primal call" of the dwelling cannot only be heard, but where there is the intent to "remain at peace within the free, the preserve, the free sphere that safeguards each thing in its nature." In this postcolonial dwelling, life is not only spared or preserved, it thrives; life knows no other mode except élan vital.

We do not think of Martin Heidegger as a radical environmentalist, and rightly so. There might, however, in "Building Dwelling Thinking" be reason to pause, albeit briefly, and consider him as such. In his poetic discussion of the "simple oneness of the four," "earth and sky, divinities and mortals," Heidegger argues: "Saving the earth does master the earth and does not subjugate it, which is merely one step from spoliation." ${ }^{12}$ Much as it is incumbent, in Heidegger's terms, upon "mortals" to desist from seeking to "master the earth" or "subjugating" it in order to avoid "spoliation," so Fanon warns against another form of political "spoliation." Heidegger's injunction bears directly upon Fanon's understanding of how the new nation will conduct its politics: "Achieving power in the name of a narrow- 
minded nationalism, in the name of race." "Saving" (or, liberating; or, preserving life) the colonized from colonialism must not, as it were, mutate into subjugation through "narrow-minded nationalism;" "spoliation" is intolerable, under whatever guise it takes, "race" or any other. If Heidegger can be dubbed a momentary radical environmentalist, then Fanon stands as an environmentalist of the postcolonial variety: that figure of the political committed to, as Heidegger might have it, to "understanding the nature of the thing,"13 he who tends to the "thing," he who cares for the earth, he who seeks to preserve the nation as indivisible from - because it is indivisible from - the sacrosanctness of the "four." The "nature of the thing," of anything, of all things, must be not only properly understood, but grasped in their relationship to other things; the radical environmentalist seeks to protect not only the earth, but humanity's relationship to every other thing that surrounds it, that inhabits it.

Fanon, in the ideological grappling, the ideological commitments, the political struggle that animates The Wretched of the Earth, makes it a text of such philosophical pertinence that it is at one with Heidegger's sensibility. Fanon's "values" is nothing but a tentative naming for "something more." Fanon rejects capitalism, is cautious about committing himself totally to the socialist project, because he senses - even if he cannot name it properly; he cannot name it properly because what he senses has, as yet, no name; because it has no name does not, however, undermine the sensory pull of "something more" - that the (re-)thinking will make something more available. What is is not enough. The new management, the new nation, is not enough; that is why there can be no "new man." It is for this immediate reason that "everything needs to be started again." For once there need be no hesitation in joining the Fanonian declarative: if what is is not enough, there is nothing to do but start again. In this instance we can dispense, if only here, dispense with the "perhaps."

Herein lies the Heideggerian challenge. How to "gather," Heidegger's term for the drawing together of things, for the drawing things into and out of themselves, drawing beyond the thing itself (gathering "expresses something that does not belong to $\left.i^{\prime \prime}\right)^{14}$, the "unconcealed" postcolonial into itself? How to, as Heidegger might insist, "presence" the "unconcealed?" How to reveal the postcolonial to itself? To "unconceal" is akin to how Heidegger explains what it takes to "save." Both of these "really mean to set something free into its own presencing."15 It is the possibility for "presencing" that converts the building into a dwelling. (It is this way that building is always subservient to, in the service of, dwelling. Building inclines toward that very "something that does not belong to it." Dwelling, as form of withholding, must give itself to building in order for building to become dwelling: dwelling is the "expression" of what building is not.) For Heidegger, however, thinking the relationship of building to dwelling is a difficult process. While he insists that "not every building is a dwelling," he 
also has considerable regard for the act of building. So much so that he acknowledges that "all building is in itself a dwelling." 16 That is not to say, and if so only secondarily, that there is no undertaking of building that is not premised on the possibility of dwelling. Rather, it is to understand that it is the desire for dwelling that motivates "all building." Dwelling comes before building. More poetically phrased, the "nature of building is letting dwell." ${ }^{17}$ The intent of the building, that in which the building is conceived, to "let dwell." Building is never, should never be, only to build; it must already be a dwelling before it is a building. Thinking the postcolonial as a dwelling precedes, for Fanon, the act of building the nation. At the core of dwelling is thinking; the act of building is not so much, though it is that too, instrumentalist - to make the nation - as it is the manifestation, the "presencing," of the thinking of dwelling.

Dwelling not only precedes building, but there can be building without the intent to dwell. Building cannot be undertaken without the Heideggerian imperative that is also, implicitly, a philosophical and political challenge: "Only if we are capable of dwelling, only then can we build." 18 Under these conditions, there must be no building that is not, before itself, thought as a dwelling. Is the nation where no new men are possible a building in which the postcolonial can dwell? Does it not, because it is only a building, already prohibit dwelling? If the building can no longer be dwelled in, if the thinking that made the building a dwelling has not been preserved, what is there to do but to start over and think again? What is there to do but start over and build a dwelling through thinking? If there is no presencing of dwelling, if there is no presencing in the dwelling, the building cannot stand. The "primal call" that is dwelling is only audible in, and because of, the thinking: "We are attempting to trace in thought the nature of dwelling." 19 There is no way to understand the relationship between building and dwelling, a relationship Heidegger traces with his customary divergences (we think building and dwelling with each other, as complementary, as one preceding the other, as mutually constitutive), except through thought. We can only come to know dwelling if we "trace" it through thought; if we understand that we must first commit ourselves to think before it will even be possible to approach dwelling.

And we must think dwelling, we must follow the trace, wherever it may lead us, because dwelling is Being. It is for this reason that it Heidegger finds it so inexplicable that, for others, "dwelling is not experienced as man's being; dwelling is never thought of as the basic character of human being." 20 If there is no dwelling in which the postcolonial is "experienced as man's being," in which dwelling is thought of as the "basic character" of the postcolonial, can the postcolonial be said to have started already? Where is the trace of thought in the postcolonial? How can the postcolonial be if not in the thinking, a thinking that accepts - as the necessary beginning dwelling as "man's being?" We must "think for the sake of dwelling." ${ }^{21}$ In 
order to dwell we must think. If this the condition of thought, then the question provoked - we might even say directly posed - by this Heidegger essay is one capable of rearticulating the principle that girds "Building Dwelling Thinking," a naming that is already an ascension, a hierarchy that moves from "building" to "thinking," is a pertinent one: if we dwell because we think, can we think without dwelling? Is the trace of dwelling inscribed in (all) thinking? Is all thinking directed toward dwelling? So that we might dwell in thought, dwell because of thought?

\section{Perhaps}

O, call back yesterday, bid time return!

- King Richard II. Act iii. Sc. 2

Where is the "presencing" of the postcolonial to be glimpsed if not in the Fanonian "perhaps?" It is the possibility for postcolonial "presencing" that Fanon, in these speculative, almost disjunctive moments, senses in The Wretched of the Earth. It is being, Fanon senses, that might be found - might be dwelling - in the "perhaps;" it is something of this magnitude that Fanon senses lies before him. "Presencing" makes of the postcolonial a dwelling, it makes the building of the nation into a dwelling; "presencing" is "unconcealed" in the act of "starting over." The postcolonial dwelling lies before Fanon, waiting - demanding - only to be thought, requiring only a thinking against the building, a thinking against the building that is not enough. Neither "presencing" nor "man's being" is easily accessible for Heidegger. The word he uses, as we know by now, is "unconcealed:" it requires that "presencing" or "man's being" be taken out of concealment. It is only possible to dwell if the building is built with dwelling in mind; if the building is built as a dwelling, not as a building.

The (postcolonial) nation against which The Wretched of the Earth struggles was constructed as a building. It is a nation that did not think of how to think a dwelling. Or, more laboriously phrased, the new nation did not think of how to build itself as a dwelling. (Fanon's distinction between the two modes of thinking - the nation - is critical here: "National consciousness, which is not nationalism, is alone capable of giving us an international dimension." $)^{22}$ "Nationalism" did not seek to understand the kind of unconcealment that makes "national consciousness" possible because it is itself nothing less than an obdurate form of concealment; or, in Heidegger's terms, it would be very difficult to find a "trace of thought" in nationalism. Because it tends so obstinately toward itself, because it has no conception of how to think - how to approach - unconcealment, it cannot not see, it cannot know, in both the colloquial and the Heideggerian sense, what lies before it. 
If it seems at times, entirely plausibly, that Fanon's distinction between "nationalism" and "national consciousness" is a precarious, less than rigorously thought attempt to enforce difference, then it is philosophically spared because of what he senses. That is, it is unconcealment toward which he reaches in The Wretched of the Earth. Whatever the conceptual limitations that mark Fanon's delineation of "national consciousness," however closely it veers toward "nationalism," whatever the amount of clarification required in order that the terms might be more easily disarticulated, there can be no doubt that Fanon understands the following: "national consciousness" is that mode of being that "expresses something that does not belong to it." Or, more importantly for our purposes, it "expresses" - it gathers us away from nationalism, so to speak - "something that does not yet belong to it." That is to say, there is "something" in Fanon's insistence upon the distinction that gathers us away from "narrow-minded nationalism," it alerts us to those who invoke "race" expediently. We must ask, and remember, with Heidegger: "What is that name which names what is called for? Surely the word "thinking.'" 23 It is always necessary to "think" the "name" in whose name we are called to mobilize, to act; it is always necessary to "think" about what the "name calls for." There can be no way to take up the "name" "nationalism" except through thought. Fanon's thought as regards the distinction might lack in assiduousness, but in its rudimentary caution it understands that "nationalism" does not belong in the postcolonial. Nationalism is the name which must be resisted, however it dissembles, whatever name it assumes for the purpose of conducting its politics. It is in the name of this resistance that, contra Heidegger, it might be possible to bring together - to gather into our thinking - "historical and philosophical knowledge." ${ }^{24}$ They might be, "by an ancient doctrine . . radically different from each other, ${ }^{25}$ but their occasional gathering together enables them to think efficaciously against "nationalism." "Historical and philosophical knowledge" might be made to dwell together against the building that is nationalism.

It is because Fanon knows the value, if you will, of "what is already there" that The Wretched of the Earth stands as a thinking about how make the postcolonial presence itself. The presencing of the postcolonial is audible in the iteration "everything must be started over again." The Wretched of the Earth is the struggle to make manifest, or reveal, like the Dasein (or Ereignis) of Heidegger's Being and Time, "what is already there." It is for this reason that the structure of Fanon's argument in The Wretched of the Earth is salient. Fanon's work builds, as it were, from the question about values through his critique of technocracy (the inadequacy of "new management") where the refrain of "starting over" first manifests itself to the constative recognition "Perhaps everything needs to be started over again."

"Perhaps" the postcolonial must be thought not in Shakespearean formulation, so redolent with nostalgia and loss, "bid time return." 
"Perhaps" the unconcealedness of the postcolonial is the thinking of temporality that will not permit of the chronological - that which would ask for the "return" of the moment. Rather, the postcolonial must be thought as a Fanonian project: the "Third World's" refusal to follow relationally after; that is, the eidos that insists that the postcolonial can only come after the colonial. If Heidegger and Fanon's arguments are in any way instructive (and theirs are, in this regard, lofty sensibilities), then it is in their ability to explicate that the postcolonial has not yet passed. The postcolonial is what lies ahead, unconcealed, it is still to come, unconcealed, because it has not been thought. That is the project: to make a dwelling (fit) for the postcolonial, that dwelling in which it would be possible to be postcolonial.

Because there is as yet no dwelling for the postcolonial, it becomes possible to say that the postcolonial has not yet begun - "Perhaps everything needs to be started again." That is, following Fanon, we were never postcolonial. There is, then, no better time to press the "perhaps" into both historical and philosophical duty because, fifty years after Fanon named the difficulties, we must ask, in his name: is there any better occasion to start again, to think on how we might be postcolonial? "What is that name which names what is called for?" Heidegger's is a contorted phrasing, but it demands, at the very least, an account of the name - the "postcolonial" and he asks what is it in Fanon's work that calls us? What does The Wretched of the Earth call for? In the name of what does it call us?

${ }^{1}$ Rüdiger Safranksi, Martin Heidegger: Between Good and Evil, trs. Ewald Osers (Cambridge, MA: Harvard University Press, 2002), 1.

${ }^{2}$ Martin Heidegger, “The Thing," Poetry, Language, Thought, translated by Albert Hofstadter (New York: Harper \& Row, 1971), 174.

${ }^{3}$ Heidegger, “Building Dwelling Thinking," Poetry, Language, Thought, op. cit., 149.

${ }^{4}$ Heidegger, "Building Dwelling Thinking," 149.

${ }^{5}$ Frantz Fanon, The Wretched of the Earth (Preface by Jean Paul Sartre), trs. Richard Philcox (New York: Grove Press, 2004), 229.

${ }^{6}$ Heidegger, "Building Dwelling Thinking," 149.

${ }^{7}$ Fanon, The Wretched of the Earth, 55.

${ }^{8}$ Fanon, The Wretched of the Earth, 55.

${ }^{9}$ Fanon, The Wretched of the Earth, 55.

${ }^{10}$ Fanon, The Wretched of the Earth, 56.

${ }^{11}$ Heidegger, “The Thing," 171. 


\footnotetext{
${ }^{12}$ Heidegger, “Building Dwelling Thinking," 151.

${ }^{13}$ Heidegger, “Building Dwelling Thinking," 153.

${ }^{14}$ Heidegger, “Building Dwelling Thinking," 153.

${ }^{15}$ Heidegger, “Building Dwelling Thinking," 150.

${ }^{16}$ Heidegger, “Building Dwelling Thinking," 149.

${ }^{17}$ Heidegger, “Building Dwelling Thinking," 160.

${ }^{18}$ Heidegger, “Building Dwelling Thinking,” 160.

${ }^{19}$ Heidegger, “Building Dwelling Thinking," 161.

${ }^{20}$ Heidegger, “Building Dwelling Thinking," 161.

${ }^{21}$ Heidegger, “Building Dwelling Thinking," 161.

${ }^{22}$ Fanon, The Wretched of the Earth, 179.

${ }^{23}$ Heidegger, “Building Dwelling Thinking," 133.

${ }^{24}$ Heidegger, "Building Dwelling Thinking," 136.

${ }^{25}$ Heidegger, “Building Dwelling Thinking,” 136.
} 